Article

\title{
The Influence of Confucian Values on Modern Hierarchies and Social Communication in China and Korea: A Comparative Outline
}

Tomasz Sleziak

\begin{abstract}
Confucianism and Neo-Confucianism, being by-products of socio-political and educational developments at various stages of Chinese history, have permeated to a varying degree several aspects of life in East Asian societies. China itself, along with its neighbouring states-such as Vietnam and Korea-despite political changes, globalization, and adoption of non-traditional systems of governance, have retained hierarchic models of communication derived from NeoConfucianism. The nature of the doctrine and the transformative processes it underwent in the course of history are still widely discussed issues, just like the degree to which the societies in China and Korean Peninsula consciously follow the ethnolinguistic, philosophical, and moral principles of Confucianism. The goal of this paper is therefore not to focus on purely metaphysical aspects of Confucianism, but rather to examine communication patterns and modes of behaviour in various aspects of daily life in China and Korea introduced in processes of Confucianisation or influenced by Confucian philosophy, by means of the combination of qualitative method and comparative analysis.
\end{abstract}

Keywords: Confucianism, values, modern hierarchies, social communication

\section{Background}

7 he core motivation behind this paper lies in the relatively-unexplored academic area encompassing connections between Confucian traditions and current mentalities of East Asian nations as well as certain spheres of public activity. Furthermore, since it is a well-established academic fact that Confucianism has persisted until the present day, the main

(c) 2014 Tomasz Sleziak

http://www.kritike.org/journal/issue 15/sleziak december2014.pdf

ISSN 1908-7330

$($ (c) $)$ BY-NC 
hypothesis and intellectual basis of the paper is the survival and persisting prevalence of this doctrine as a coherent, independent, and influential sociopolitical system of thought in East Asia, distinguishable from other cultural traditions of the region. It has also been assumed that the differences in terms of adoption and adaptation of Confucianism in China and Korea should not be viewed as purely dichotomic, but rather as processes which share common roots and cultural denominators. In order to verify these assumptions in a satisfactory manner, the examination of the ties binding pre-modern and modern societies of Korean Peninsula and China, as well as of the differences between Korean and Chinese applications of Confucian ideology, was performed with the aid of both traditional and contemporary literature on wide-ranging subjects from the field of East Asian studies and relevant humanities. The framework of my nine-month research leading to the compilation of the paper was centered on intellectual history and sociology of China and Korea along with specific aspects of linguistic hierarchism in Chinese and Korean cultures and the application of socio-political and philosophical doctrines in pre-modern and modern East Asia Research methods applied include comparative analysis (extending to literary materials, relevant aspects of Chinese and Korean Confucianism, specific ethnolinguistic elements and traditional and modern sociological thought of the region of East Asia) and qualitative line of enquiry. Online articles and sociological data were also of importance in the course of research, as they presented relatively up-to-date state of East Asian societies and data pertaining to the acceptance of Confucian values. Lastly, the author would like to extend words of gratitude to Prof. Andrea Riemenschnitter, Prof. Martina Deuchler, Dr. Ralph Weber, Prof. Pankaj Mohan, Dr. Anders Karlsson and Dr. Lars Laamann whose expertise has greatly contributed to the structure and topicality of the paper.

\section{Earliest historical basis of Confucianism}

Confucianism is a complex and often misinterpreted system of beliefs. This applies not only to its theoretical and functional aspects, but also to its western name. The historical figure Kong Qiu has not given a formal name to his doctrine, and the term "Rujia" (chin. 儒家), which is typically translated as "scholarly tradition" or "the school of sages," only appears in Han dynastic period, primarily in the writings of Sima Tan 司馬談. Furthermore, as indicated by surviving documents from the early Zhou period (such as the "Classic of History," also translated as "Book of Documents," chin. Shujing 書經), several ideas often attributed to Confucianism in fact have origins traceable to the oldest ethical and sociological thoughts of China. Despite that fact, the compilatory work of

(c) 2014 Tomasz Sleziak

http://www.kritike.org/journal/issue 15/sleziak december2014.pdf

ISSN 1908-7330

(cc) $\mathrm{BY}-\mathrm{NC}$ 
Confucius, as well as his own theoretical contributions, cannot be overlooked as this doctrinal amalgamate was seemingly such an effective framework for education and governance systems that, despite the downfall of feudal structures associated with it, it survived to this day in mentalities of East Asian nations. Confucius repeatedly stressed the necessity of the balance between humaneness (chin.Ren 仁, kor. Yin 인), ritual propriety (chin. Li 禮, kor. Ye 예), righteousness (chin. Yi 义/義, kor. Ui 의) and filial piety (chin. Xiao 孝, kor. Hyo 효), which, according to him, correlated with the concept of a virtuous government, harmonious society, ${ }^{1}$ and later came to be perceived as directly connected to the idea of Five Cardinal Relationships (parent-child, ruler-minister, husband-wife, elder-younger, and friend-friend), which are in turn frequently concluded, at least partially, to constitute the core of extant Confucian values in East Asia and embody the set of rules by which an individual is bound in his or her interactions with the rest of society. ${ }^{2}$ Confucius, however, did not concern himself with overly metaphysical speculations, and it was the work of successive generations of scholars that led to creation of various "cosmological anthropologies," which are collectively treated under the purely western term of Neo-Confucianism and have considerably influenced socio-political and intellectual environments of East Asia from the ninth to nineteenth century. The historical context of Confucianism should therefore, along with its changing pathways and reinterpretations, be analyzed in order to understand the placement of the philosophy in cultures of modern China and Korea.

\section{Confucian ritual and philosophical traditions and their points of divergence}

The key point in any research concerning the status of Confucianism in China and Korea is the role of nobility and its ties with various cultural heritages of the region. The application of both aspects of Confucian philosophy-conservatism and the transformative principle - the influence of the hereditary aristocracy, originally deeply respected by Confucius himself, had severely declined during Chinese Tang and Sung dynastic periods, giving place to a scholarly class of administrators. Among the main

\footnotetext{
${ }^{1}$ Wing Tsit Chan, A Source Book in Chinese Philosophy (Princeton, New Jersey: Princeton University Press, 1963), 14-16

${ }^{2}$ Uichol Kim and Seung-hwan Lee, "The Confucian Model of Morality, Justice, Selfhood and Society: Implications for Modern Society," in The Universal and Particular Natures of Confucianism, Proceedings of The $8^{\text {th }}$ International Conference on Korean Studies (The Academy of Korean Studies, 1994), 167-209.
}

(C) 2014 Tomasz Sleziak http://www.kritike.org/journal/issue 15/sleziak december2014.pdf ISSN 1908-7330 
purposes of this new social formation was not only the creation of official cadres practicing the "virtuous" governance according to the thendeveloping Neo-Confucianism, but also the dissemination of the particular "cosmological anthropology" by the scholarly caste among all social strata. ${ }^{3}$ While the details of this process will be discussed further on, it should be noted here that the shaping of Neo-Confucian metaphysics into a credible socio-political doctrine of harmony in essence not only constituted a largely successful counterattack against the popularity of Buddhist and Taoist thought in rural areas, but also gave additional support to the traditional corpus of ancestral and seasonal ceremonies; these rituals, despite their partially pre-Confucian origins, ${ }^{4}$ have eventually become characteristic to the religious aspects of Neo-Confucianism in both China and Korea. However, the differences between processes of Confucianisation initiated in these two traditional countries in different periods of time had traditionally been significant. This fact stemmed from the cult of authority, which by the end of Goryeo period (918-1392) came to encompass the figure and literary heritage of such figures as Cheng Yi 程頣; Cheng Hao 程影, and most importantly Zhu Xi 朱喜 in Korean Peninsula. ${ }^{5}$ Common to Korea and China was the performance of these rituals - either in the form of familial and household cults or as a pseudo-religion of state-along with reverence to $\mathrm{Zhu} \mathrm{Xi}$, who expanded upon their role in perceived anthropological and cosmological processes by borrowing terminology from Buddhism and Taoism in order to explain the relationship between the Heaven, human nature, principle, material force, and the way through which an individual may attain qualities of a sage ${ }^{6}$ akin to idealized rulers of old. But it was the latter area in which an individual was granted the higher possibility of personal development within the scope of Neo-Confucian culture, as the cultural root of Cheng-Zhu orthodoxy in Korea was practically an exclusive domain of the Yangban (kor. 양반) scholar-officialdom.

On the other hand, the access to the higher levels of career and the core of both the state affair and Confucian culture was notably easier in China. This culture has been for a long time tied to the specific form of bureaucracy present within the sinic cultural sphere, which was in many

\footnotetext{
${ }^{3}$ Romeyn Taylor, "Chinese Hierarchy in Comparative Perspective," in The Journal of Asian Studies, 48:3 (Aug. 1989), 490-511.

4 Benjamin I. Schwartz, The World of Thought in Ancient China (Cambridge, Massachusetts: Harvard University Press, 1989), 53-55.

${ }^{5}$ Martina Deuchler, “Neo-Confucianism in Early Joseon Dynasty: Some Reflections on the Role of Ye," in Korean National Commission for UNESCO, eds., Korean Philosophy: Its Tradition and Modern Transformation (Elizabeth, New Jersey and Seoul: Hollym, 2004), 43-54.

${ }^{6}$ Pratoom Angurarohita, "Buddhist Influence on the Neo-Confucian Concept of the Sage," in Sino-Platonic Papers, 10 (June 1989), 1-31.

(C) 2014 Tomasz Sleziak

http://www.kritike.org/journal/issue 15/sleziak december2014.pdf

ISSN 1908-7330

(cc) $\mathrm{BY}-\mathrm{NC}$
} 
ways an amalgamate construct of pure Confucian code of conduct and the legalist heritage of Qin period; 7 from sixteenth to the early nineteenth century, it was perceived as an ideal system of governance by the eighteenth-century European scholars, based on the exaggerated or incomplete information they received from Jesuit missionaries. Modern specialists in the field of East Asian studies call validity of this "sino-centrism" into doubt, as the top ruling spheres in both China and Korea were not the embodiments of an enlightened rulership, but they, in fact, functionally represented variants of aristocratic autocracy. ${ }^{8}$ In accordance with the outlook of Voltaire, ${ }^{9}$ however, the "religious" setting of China and (by extension) Korea may have-to a certain degree-resembled deistic concepts of the western Enlightenment, ${ }^{10}$ as anthropomorphic metaphysical beings were not significant within the scope of state cults, and the concepts of Heaven and Ancestors may be seen as dissimilar to the Judeo-Christian images of "God." These concepts were instead of purely moral-philosophical nature, performance of rituals directed towards them being considered essential to the survival of the state, society and ruler's virtue since the Zhou period. ${ }^{11}$ Since cosmological and sociopolitical dimensions of what eventually came to be called the teaching of the scholars (chin. Rujia 儒家) were connected with each other through a distinctly sinophone interpretation of the principles of cause-and-effect, universal correlation, and cyclical nature of life, the behavior of any individual or social stratum ${ }^{12}$ could potentially influence Heaven and Earth and vice versa through complex reconfigurations additionally involving such factors as five elements, ${ }^{13}$ thus leading to ascription of the highest possible priority to maintenance of harmony and order in societal activities and state administration. Therefore, it may be concluded that while Confucius himself

7 Benjamin A. Elman and Alexander Woodside eds., Education and Society in Late Imperial China, 1600 - 1900 (Berkeley: University of California Press, 1994), 551.

8 Paul S. Ropp ed., Heritage of China Contemporary Perspectives on Chinese Civilization (Berkeley: University of California Press, 1990), 79, 238.

9 Voltaire, "Selections from the Philosophical Dictionary," 1-2, accessed December 29 2014, <http://homepages.gac.edu/ arosenth/160/Voltaire_Selections.pdf>.

${ }^{10}$ John K. Fairbank, Edwin O. Reischauer and Albert M. Craig, East Asia The Modern Transformation (Boston: Houghton Mifflin Company, 1965), 55-58.

${ }^{11}$ Scott Cook, "The Debate over Coercive Rulership and the 'Human Way' in Light of Recently Excavated Warring States Texts," in Harvard Journal of Asiatic Studies, 64:2 (Dec., 2004), 399-440.

12 This includes the imperial authority, which reinforced its authority by the means of being metaphysically-perceived-in terms of supposedly being granted by Heaven, the embodiment of the highest virtue and principle-yet not immutable prerogatives believed to be formulated by the Duke of Zhou (chin. Ji Dan 姬旦) and known collectively as the mandate of heaven (chin. Tian Ming 天命).

${ }^{13}$ Tien-Rein Lee, "Heaven, Earth and Humans: Color Harmony in Chinese Culture," in Obuda University e-Bulletin, 3:1 (2012), 155-164, 29 December 2014, <http://uni-obuda.hu/ebulletin/Lee_3.pdf $>$.

(C) 2014 Tomasz Sleziak http://www.kritike.org/journal/issue 15/sleziak december2014.pdf ISSN 1908-7330 


\section{CONFUCIAN VALUES}

was not explicit in his appraisal of the supernatural, the theories concerning the role of humans in the universe or the origins of their emotional as well as intellectual faculties are core elements of Confucianism and have constituted the integral part of this essentially humanistic philosophy-unlike more esoteric beliefs of Taoists and Buddhists-even before the advent of NeoConfucian movements in Sung dynastic period. ${ }^{14}$ This in turn brings further an additional problem of legitimacy and policy-making. Despite the frequent political volatility in China and Korea and the fluctuating trust towards the ruler or administration, the scholar-literati were the true ruling and relatively stable (in terms of their administrative responsibilities and personal lifestyles) social class, which through long academic disputes formulated official doctrines to be followed by both the government and commoners_-including those who attempted to raise their status through participation in the official examination system-though in the case of the latter (given the frequent economic hardships and physical labor), the appropriation of Confucian precepts usually meant conservative repetition of seasonal and ancestral rites (either explicitly supported by the literary canon or tolerated by authorities) as well as acceptance of traditional hierarchies and interpersonal communication. Eventually, despite the highly elaborate cosmology and ritual corpus of Neo-Confucianism, most of their constituents had lost their traditional background and significance in modern China and Korea, and Neo-Confucianism itself ceased to be the state ideology, transforming into an internalized, underlying ethnolinguistic system, with age and gender remaining prime defining factors of its intricacy. In order to understand the magnitude of these changes, a short analysis and comparison between certain aspects of pre-modern China and Korea and the influence Confucianism exerted on socio-political settings and interpersonal communication in these two countries must be presented.

\section{Outline of the Evolution of Confucian philosophy and social models}

The first key factor regarding differences between Confucian states of China and Joseon Korea lies in the processes of gentrification. The period of disorder following the downfall of the Han dynasty and the subsequent time of peace under Sui, Tang, and Sung dynasties marked the end of most privileges associated with traditional aristocracy. ${ }^{15}$ Chinese NeoConfucianism-most importantly the texts that came to be venerated as

\footnotetext{
${ }^{14}$ Luke J. Sim, S.J. and James T. Bretzke, S.J., "The Notion of Sincerity (Ch'eng) in The Confucian Classics," in Journal of Chinese Philosophy, 21 (1994), 179-212.

${ }^{15}$ Edwin O. Reischauer and John K. Fairbank, East Asia The Great Tradition (Boston: Houghton Mifflin Company, 1960), 186-187.

(c) 2014 Tomasz Sleziak

http://www.kritike.org/journal/issue 15/sleziak december2014.pdf

ISSN 1908-7330

(cc) BY-NC
} 
"classics" (including such works as "The Book of Documents," "The Book of Odes," "Spring and Autumn Annals," "Analects," and "The Book of Mencius") - formed the basis for examination system which in turn became the main method of social advancement. Many official positions could be inherited; however, since the seventh century $\mathrm{AD}$, academic effort and resources rather than birth could determine one's life. The landholding class, financially placed at the top of society, often dominated the examination system, though it no longer had any specific, traditional privileges placing it ritually above other social strata. However, Mark Edward Lewis, a specialist in Tang dynastic period, makes an important remark on the concentration of the highest-level academic institutions in the capital, which, coupled with certain rank- and family-based restrictions, complicated the attempts of provincial candidates at career advancement. ${ }^{16}$ Nonetheless, the situation in Korean Peninsula of the late Goryeo period was very different as regards the society's structure; the reasons for survival and prominence of the semiaristocratic Yangban scholar-officialdom were numerous, despite the nominal adoption of Ming Chinese educational curriculum in the form of Confucian textual studies and the oft complex, "metaphysical"17 methods of governance as outlined by the orthodox Cheng-Zhu school of NeoConfucianism, which envisioned equal chances of advancement for all members of society..$^{18}$ Among these reasons is the degree to which the landholding families were tied to the royalty of the late Goryeo period as well as to the ruling Yi family of Joseon, which was significantly high in the history of East Asian gentry. ${ }^{19}$ Furthermore, there were several administrative restrictions enacted by Joseon policy-makers, which impeded the efforts of persons outside Yangban kinship groups to engage in a career of a scholarofficial..$^{20}$ It may be said that while in China the position of a "gentleman" (chin. Junzi 君子) was envisioned by Confucius and later scholars as one that could be reached by one's own effort, in Joseon the analogous term Gunja (kor.군자) came to be associated almost exclusively with the hermetic Yangban class.

${ }^{16}$ Mark Edward Lewis, China's Cosmopolitan Empire the Tang Dynasty (Cambridge, Massachusetts and London: The Belknap Press of Harvard University Press, 2009), 203-204.

17 This is in terms of describing all forms of social interactions as placed within an intricate system of cosmological factors, such as the five elements, the principle and the material force, and the institutionalized ancestral worship.

${ }^{18}$ Yung Sik Kim, The Natural Philosophy of Chu Hsi 1130 - 1200 (American Philosophical Society, 2000), 123, 247, 271, 278.

${ }^{19}$ John Duncan, "The Korean Adoption of Neo-Confucianism: The Social Context," in Walter H. Slote and George A. de Vos eds., Confucianism and the Family (Albany: State University of New York Press, 1998), 75-90.

${ }^{20}$ Yong-Ho Choe, "Commoners in Early Yi Dynasty Civil Examinations: An Aspect of Korean Social Structure, 1392 - 1600," in The Journal of Asian Studies, 33:4 (Aug. 1974), 611-631. 
Although both in China and Korea the ruling social spheres acted as the main disseminators of Confucianism, the commoners were active participants in the cultural activities of their states, or at least were faithful recipients of the government's policies associated with Confucianism, which in turn came to be linked with collective action and responsibility as the main factors shaping an individual into a "complete" being. ${ }^{21}$ This type of a topdown policymaking had its official roots in the Sung and Ming periods, when dialogues between philosophers and the imperial environment were common; the scholarly and political authority of such persons as $\mathrm{Zhu} \mathrm{Xi}$, his chief opponent Lu Xiangshan 陸象山, and the orthodox position of the former have all resulted from such encounters, as Theodore de Bary describes in his brilliant analysis of Sung period academic discourses. ${ }^{22}$ However, Brian E. McKnight points out that these debates, besides being purely theoretic, also had a practical dimension, and several of Sung Neo-Confucians ${ }^{23}$ and later periods in China and Korea have also engaged in legal matters and community administration. In these terms, the cooperation between village communities and people living within them was envisioned by NeoConfucian scholar-officials as a mechanism which could — at least in theoryalleviate much of the administrative problems of the state, especially in its outlying regions. Such sustainable system of community compacts was devised in China and subsequently copied in Joseon Korea; Martina Deuchler extensively elaborated on this topic in her work. ${ }^{24}$ Confucianism -both its moral principles and academic curriculum — acted as the main basis for these social structures. Along with the aforementioned ancestral rituals, these semiartificial socio-political systems were based on an idea of harmony connected to not only status and education, but also gender inequality, ${ }^{25}$ which nonetheless brought relative internal stability to East Asian states for the duration of long dynastic cycles. Many hierarchic speech patterns have developed or, in more cases, were reinforced ${ }^{26}$ during that time as a result of

${ }^{21}$ Sor-Hoon Tan, "Can there be a Confucian Civil Society," in Chong Kim-Chong and Tan Sor-Hoon eds., The Moral Circle and The Self (Chicago and La Salle, Illinois: Open Court, 2003), 193-218.

${ }^{22}$ William Theodore de Bary, Neo-Confucian Orthodoxy and the Learning of the Mind-AndHeart (New York: Columbia University Press, 1981).

${ }^{23}$ Brian E. McKnight, Law and Order in Sung China (Cambridge, USA: Cambridge University Press, 1992), 20-24.

${ }^{24}$ Martina Deuchler, "The Practice of Confucianism: Ritual and Order in Choson Dynasty Korea," in Benjamin A. Elman, John B. Duncan and Herman Ooms eds., Rethinking Confucianism: Past and Present in China, Japan, Korea, and Vietnam (Los Angeles: UCLA Asian Pacific Monograph Series, 2002), 293-334.

${ }^{25}$ Patricia Buckley Ebrey, Confucianism and Family Rituals in Imperial China A Social History of Writing About Rites (Princeton, New Jersey: Princeton University Press, 1991), 145-166.

26 Lucien Brown, Korean Honorifics and Politeness in Second Language Learning (Amsterdam and Philadelphia: John Benjamins Publishing Company, 2011), 20-22.

(c) 2014 Tomasz Sleziak

http://www.kritike.org/journal/issue 15/sleziak december2014.pdf

ISSN 1908-7330

(cc) BY-NC 
the influence Confucian doctrine exerted on the culture of the nobility as well as the general relations between high and lower social strata, and, consequently, through top-down approach, on the daily life of commoners. It may definitely be concluded that these developments were an attempt at emulation of traditional China's (where the Confucian ideology started to exert its influence at a much earlier stage of social organization) culture and communication patterns; regardless of the dubious results, various fields of literature, especially the art of commentary, philosophical dispute and poetry were nonetheless given further prominence due to their importance in the system of official examination. However, the aforementioned tendency towards group-thinking and collectivism had eventually led to political factionalism in both China and Korea, which in turn brought about the decrease of the ruler's authority and of the administrative efficiency, as it was impossible for politicians of different ideological affiliations to formulate a coherent state policy in an environment, where every faction primarily had focused on its own political agenda and typically rejected academic opinions of opposing groups. This was one of the biggest shortcomings of Joseon's politics the Sirhak (kor. 실학, literally 'real learning' or 'practical learning') movement lamented. ${ }^{27}$ Moreover, this attitude, coupled with the aforementioned cult of authority and reverence to the ethnic Chinese culture, has caused intellectual isolation of Korea. For example, such developments as the gradual loss of popular support towards Buddhism, the official disdain towards the precepts of the heterodox Lu-Wang mind-and-heart school in Joseon, and the XIXth century clash between Neo-Confucian ritualism and Christianity ${ }^{28}$ may be directly connected to the staunch intolerance of Joseon's scholar-officialdom and the relative value uniformity among Koreans under the Yi dynasty. ${ }^{29}$ This intolerance towards doctrines unendorsed by the government was, however, virtually unknown within Korean society in earlier times. While the exact date of Confucianism's arrival on the Peninsula is unknown, one may assume based on extant resources that it appeared jointly with Buddhism between third and fifth centuries $\mathrm{AD},{ }^{30}$ and until the late Goryeo period (918-1392) it had influenced education curriculum and political organization in Korea to a limited degree, for instance, by providing a basis for the honor code of the Silla Hwarang, its popularity being much

\footnotetext{
${ }^{27}$ Don Baker, "Practical Ethics and Practical Learning: Tasan's Approach to Moral Cultivation," in Acta Koreana, 13:2 (Dec. 2010), 47-61.

${ }^{28}$ Robert E. Buswell and Timothy S. Lee eds., Christianity in Korea (University of Hawai'I Press, 2006), 287.

${ }^{29}$ Michael J. Seth, A History of Korea From Antiquity to the Present (Plymouth, UK: Rowman and Littlefield Publishers Inc., 2011), 179.

${ }^{30}$ Mark Peterson and Philipp Margulies, A Brief History of Korea (New York: Infobase Publishing, 2010), XIII.
}

(C) 2014 Tomasz Sleziak http://www.kritike.org/journal/issue 15/sleziak december2014.pdf ISSN 1908-7330 
lower than Buddhism among non-elites. The wake of the Joseon period brought an end to these inter-doctrinal dynamics; consequently Confucianism started to extend a far-reaching influence on Korean society by transforming traditional customs, providing new regulations for them, and dominating socio-political environment of Korea at the expense of Buddhism and Shamanism.

The concept of belonging to a defined group and conforming to its goals, beliefs, and general lifestyles, can thus be seen as common denominator of interpersonal relations and socio-political processes of all social strata in traditional China and Korea-the notion that has largely survived the fall of feudality. However, as previously mentioned, the official paths of career, Confucian moral norms, and peer-pressure factored in a development of a Korean individual of Joseon period to a much higher degree than in the case of his Ming Chinese contemporary, as well as presenting his personal freedom of thought and choice as highly limited, at least from the modern perspective. ${ }^{31}$ Even in the private environment of the family, an individual was bound by strict rules defining his or her position and interpersonal relations, seemingly more centered on the maintenance of ritual propriety than of humaneness as envisioned by Confucius. These, as stipulated by Zhu Xi in his Family Rituals, were applied much more vehemently in Joseon than in Ming and Qing China; for instance, the low standing of secondary wives and their offspring as well as the social issues stemming from this type of family setting was extraordinary in pre-modern East Asia. ${ }^{32}$ Still, a question remains, if these limitations - in one way or another associated with Confucianism-have retained their significance into the present day East Asian states, and whether Confucian doctrine can serve as a positive agent of social mobilization and growth in today's China and South Korea.

\section{The wake of modernity in East Asia and clashes between Confucianism and foreign doctrines}

\section{a) The first half of the twentieth century in China and Korea}

In the first decades of the twentieth century, both the occupational Japanese forces in Korea and most of the forces of modernization in China considered state Confucianism to be among the chief agents responsible for

\footnotetext{
${ }^{31}$ James B. Palais, "Confucianism and The Aristocratic/Bureaucratic Balance in Korea," in Harvard Journal of Asiatic Studies, 44:2 (Dec. 1984), 427-468.

32 Peter H. Lee and Theodore de Bary eds., Sources of Korean Tradition Vol.I (New York: Columbia University Press, 1997), 317.

(c) 2014 Tomasz Sleziak

http://www.kritike.org/journal/issue 15/sleziak december2014.pdf

ISSN 1908-7330

(cc) BY-NC
} 
the economic and political decline of the far-east monarchies. The fact that the downfall of Joseon and Qing dynasties was almost immediately followed by the abolishment of the official examination system is a supplementary proof of the direct ties between Confucianism and the traditional politics of the aforementioned states, and of the negatively perceived role of the Confucian philosophy as the main factor preventing modernization. Among Chinese scholars and reformers active during the republican period, Kang Youwei 康有為 was especially vocal in his criticism of the orthodox Confucianism and its ties with the rulership..$^{33}$ It was then that, in the process of the development of their own nationalistic doctrine, Koreans started to view themselves as a single nation belonging in a specific geopolitical reality, and not as a set of sharply divided feudalistic classes. ${ }^{34}$

As the external pressure towards modernization increased in China and Korea, the official aspect of Confucianism has largely faded, although extensive reconstructions of the ritualistic corpus of the doctrine have been carried out since the end of the Korean War. Due to the abolition of privileges of the Korean Yangban class, the former scholar-officials were required to become accustomed to new cultural and socio-political environments. Consequently, many of their kinship groups, by utilizing the Japanese capital and leftover infrastructure, have, as Tan Soo Kee notes, provided an intellectual and technological basis for the indigenous Chaebol 채벌 conglomerate system. ${ }^{35}$ Meanwhile, however, the struggle for independence and the realistic needs of the occupied Korean people had made it difficult for a conservative doctrine such as Confucianism to serve the role of a main drive of the nation towards freedom; among ideologies inspired by foreign philosophies and policy models, the capitalist and socialist offshoots of nationalist thought eventually proved more attractive to the majority of society. Similar ideological struggles took place in China, though it must be noted that despite the chaotic governance of the republican period, the public discourse nonetheless faced fewer restrictions than in the case of Korea, which may have contributed to the presence of a very active intellectual environment as well as - indirectly - to a number of ideological clashes in the "middle country," as Leigh Jenco remarks in his article. ${ }^{36}$ As a result of

${ }^{33}$ Lawrence R. Sullivan, "Intellectual and Political Controversies Over Authority in China: 1898 - 1922," in Peter D. Hershock and Roger T. Ames eds., Confucian Cultures of Authority (Albany: State University of New York Press, 2006), 171-214.

${ }^{34}$ Gi-Wook Shin, Ethnic Nationalism in Korea Genealogy Politics and Legacy (Stanford, California: Stanford University Press, 2006), 5-6.

${ }^{35}$ Soo Kee Tan, "Influences of Confucianism on Korean Corporate Culture," in Asian Profile, 36:1 2008, 9-20.

${ }^{36}$ Leigh K. Jenco, "'Rule by Man' or 'Rule by Law' in Early Republican China: Contributions to a Theoretical Debate," in The Journal of Asian Studies, 69:1 (Feb. 2010), 181-203. 
the discourse between supporters of Confucianism with the adherents to such philosophies as western humanism and rationalism, the so-called New Confucianism was formulated, supporters of which—such as Mou Zongsan 牟宗三—strived to appropriate the ancient doctrine to the reality of the twentieth century. ${ }^{37}$ As for the familial aspect of Neo-Confucian thought, it had largely survived in both of these countries in the form of household cults, extensively described in Choi Joon-Sik's book, 38 though the degree of this survival is debatable and adherence to their tradition is steadily decreasing, with most of the supporters of these cults being, as Choi points out, the inhabitants of rural regions. The rising popularity of Christian denominations in East Asia has also affected the popularity of ancestral rituals and related forms of Neo-Confucian cult. However, as these rituals, in their modern form, represent purely private aspect of life in East Asia, they will not be further enquired into in this paper.

As much as the structure of Chinese and Korean societies developed, their modes of communication underwent changes as well. The rising popularity of the communist movement in China raised the issue of analphabetism among lower social strata, and consequently the idea of simplification of traditional characters started to be proclaimed as early as the beginning of the twentieth century, but actively applied only in the 1950s in mainland China. ${ }^{39}$ Meanwhile, in Korean Peninsula, the majority of the modern political forces considered the use of Hanmun (kor. 한문, chin. 漢文, lit. classical Chinese writing) in daily life to be outdated, complicated, and potentially dangerous to the uniqueness of the national culture, ${ }^{40}$ therefore, shifting the focus to the formerly shunned, indigenous Hangul phonetic alphabet. Both of these ethnolinguistic processes were directly connected to the aforementioned reinterpretations of Confucianism, as the use of the traditional Chinese characters used to be a denominator of the ruling, privileged class in China and Korea. This, however, did not mean the complete abandoning of the Confucianism-influenced communication. While in China the system of honorifics had been greatly simplified, the relationship between speaker and listener, their individual statuses and the spatialtemporal setting of their conversation have retained their importance in Korean day-to-day communication despite various new structural influences and loan words taken predominantly from such languages as Japanese and

\footnotetext{
37 Xinzhong Yao, An Introduction to Confucianism (New York: Cambridge University
} Press, 2000), 242-247.

38 Joon-Sik Choi, Folk-religion, The Customs in Korea (Seoul: Ewha Womans University Press, 2005)

${ }^{39}$ Linsun Cheng ed., Berkshire Encyclopedia of China (Great Barrington, Massachusetts: Berkshire Publishing Group, 2009), 263-264.

${ }^{40}$ Seth, A History of Korea From Antiquity to the Present, 258-261.

(c) 2014 Tomasz Sleziak

http://www.kritike.org/journal/issue 15/sleziak december2014.pdf

ISSN 1908-7330

(cc) $\mathrm{BY}-\mathrm{NC}$ 
English in the first half of the twentieth century as the result of the Peninsula's new geopolitical situation. ${ }^{41}$

The Japanisation conducted by the occupational forces in Korea and attempted in certain regions of China (such as Manchuria) brought upon yet another significant factor of change - the revival of Buddhism, which for many centuries was defensive against Neo-Confucianism in China and Korea. Although the Japanese form of this religion was in many aspects different from the ones practiced in the continental East Asia, the side effect of the introduction of the foreign, syncretic (in terms of its strong connection with Shinto) doctrine was the revival of the indigenous Buddhist thought in the aforementioned countries, as well as the apparent decrease of Confucian rituals performed in the public space, which was also influenced by policies of the Japanese occupational government. ${ }^{42}$ Various Christian denominations have garnered following as well, though their success had been severely limited due to both indigenous and Japanese opposition to these movements, ${ }^{43}$ as well as by the perceived incompatibilities between canonical rules of Christianity and Confucianism, most importantly the long-standing problem of Confucian ancestral cults. All of these socio-political issues contributed to the practical relegation of ritualistic Confucianism to the private sphere in China and Korea; however, despite the new linguistic and socio-political developments, an arguably Confucian basis for interpersonal communication in these countries has retained its importance. The new political orders and military confrontations of the second half of the century have brought further changes to the perception of Confucianism and its sociopolitical role in East Asia.

\section{b) The new socio-political orders of China and Korean Peninsula in the second half of the twentieth century}

The end of the Second World War and the doctrinal, political, and ethnical divisions caused by it had far-reaching consequences for Confucianism in China and Korea. Existence of two states-the People's Republic of China and the Republic of China (Taiwan)-each of them aspiring to represent the Chinese people and their values-was directly mirrored by the situation in the Korean Peninsula. The principles of Marxism, Leninism, and Maoism (in mainland China), augmented, in the case of North

${ }^{41}$ Ki-Moon Lee and Robert S. Ramsey, A History of Korean Language (New York: Cambridge University Press, 2011), 191-192, 299-305.

${ }^{42}$ Henrik Sorensen, "The Attitude of the Japanese Colonial Government Towards Religion in Korea (1910-1919)," in Copenhagen Papers in East and Southeast Asian Studies, 8 (1993), 49-69.

${ }^{43}$ Fairbank, Reischauer, and Craig, East Asia The Modern Transformation, 760-761.

(C) 2014 Tomasz Sleziak

http://www.kritike.org/journal/issue 15/sleziak december2014.pdf

ISSN 1908-7330 
Korea, by the original "Juche" idea of autarchy and ideological independence, viewed any religious conduct - or any explicitly connected to monarchism as a potentially disruptive social activity. Despite the gradually introduced modifications to this state policy in the People's Republic of China, the environment for official discourse on Confucianism, Buddhism, and Christianity still faces many restrictions, and the situation in this regard is especially difficult in the Democratic People's Republic of Korea. On the contrary, the openly nationalist Kuomintang party, which became the governing body of Taiwan's "Republic of China," stated the need to protect what it perceived as the traditional Chinese culture, which in turn encompassed both religious Taoism and Neo-Confucianism; this policy had extensive support from various "patriotic" refugee scholars who escaped communist persecutions at that time. ${ }^{44}$ The case of the Republic of Korea (South Korea) was somewhat similar to Taiwan; Syngman Rhee 이 승만, Park Chung-Hee (Pak Jeong-Hui 박 정희) and Chun Doo-Hwan (Jeon Doo-Hwan 전 두환), while maintaining a security-centered relationship with the United States, considered Confucianism and Shamanism not only as the core of the national thought, but also as the underlying theoretical support for the nationalized economy. 45

The paternalistic control exerted by an authoritarian figure or group of individuals on an extensive, profit-driven structure (which are, up to present time, common in East Asia, including Japan) has been frequently described as such application of the Confucian top-down approach in modern times. The interesting aspect of this situation is the situation in North Korea with the dominance of the ruling Kim family, which in turn resembles the mechanisms behind the public authority of Yi kinship groups in Joseon Korea, as one may conclude from Paul French's analysis of the subject. ${ }^{46}$ Despite this characteristic of East Asian societies, it was only recently, as will be detailed later, that the governments of the mainland China and South Korea openly started expressing their wish to use Confucianism in the process of legitimization of their own rule. Although Confucianism had not been listed among the legal religions in communist China, the tenure of Deng Xiaoping 邓小平 constituted an important landmark as regards the official perception of the traditional doctrine, and since that time, the positive outlook on non-cultist aspects of Confucianism has been on the rise among

44 Shu-Hsien Liu, Essentials of Contemporary Neo-Confucian Philosophy (Westport, Connecticut, London: Praeger, 2003), 35, 54, 111-112.

${ }^{45}$ Henry C.K. Liu, "Korea Under Park Chung-Hee," in Asia Times, 25 October 2006, $<$ http://www.atimes.com/atimes/Korea/HJ25Dg01.html>.

${ }^{46}$ Paul French, North Korea The Paranoid Peninsula A Modern History (London and New York: Zed Books, 2005), 63-64.

(c) 2014 Tomasz Sleziak

http://www.kritike.org/journal/issue 15/sleziak december2014.pdf

ISSN 1908-7330

(cc) BY-NC 
the Party members and official policies of the state. ${ }^{47}$ Furthermore, the continuous survival and thriving of kinship structures in mainland China is believed to be supported not only by socialist, collectivist thought, but also by Confucianism and its tenets pertaining to proper relationships between family members. ${ }^{48}$ The aforementioned persistence of indigenous beliefs in Taiwan has been of a different nature, as the authority of Taoist deities, Buddhist sacred figures, and Confucian scholars has come to be respected in a purely religious manner among islanders; this approach along with the "westernization" (or "pop-culturization") of Confucianism is, to a certain degree, considered by many modern scholars to be against the original teachings of Confucius. ${ }^{49}$ It was in Taiwan, however, that the scholars representing the movement of "New Confucianism" found their solace after the defeat of the Kuomintang on the continent. ${ }^{50}$ Although these developments have been significant from a cultural point of view, many aspects of East Asian societies have changed since then, and along with them, the perception of Confucianism. The democratization of South Korea and the various, complex socio-economic and political changes in the People's Republic of China, which started in the second half of the 1980s, have constituted the chief causes of new rearrangements of the role of the "doctrine of the sages" in day-to-day life of China's and Korea's societies.

\section{South Korea}

c) The Contemporary Situation of Confucianism in China and

The rapid economic rise of China and South Korea, coupled with the political opening of the former, had both positive and negative results in sociological terms. Education and entertainment underwent significant changes, which were, at least to a certain degree, related to the re-examination of the modern forms of Confucianism. Nationalist thought partially absorbed cosmopolitan interpretation of Confucian ideology, which has since been stated to emphasize cultural exchanges ${ }^{51}-$ South Korea's embracing of

\footnotetext{
${ }^{47}$ Randall Peerenboom, China Modernizes threat to the west or model for the rest? (Oxford and New York: Oxford University Press, 2007), 107-108.

48 Yunxiang Yan, "The Individualization of Chinese Society," in London School of Economics Monographs on Social Anthropology, 77 (2009), 100.

49 Xiuping Hong, "The Characteristics and Prospect of the Confucian Academy: A Commentary on Jiang Qing's Ideas on the Confucian Academy," in Fan Ruiping ed., The Renaissance of Confucianism in Contemporary China (New York: Springer, 2011), 185 -204.

${ }^{50}$ Jeffrey Richey, Confucianism Historical Development Modern Age, in Patheos Library, 8 May 2013, <http://www.patheos.com/Library/Confucianism/Historical-Development/ModernAge.html $>$.

${ }^{51}$ Arif Dirlik, "Confucius in the Borderlands: Global Capitalism and the Reinvention of Confucianism," in Boundary 2, 22:3 (Autumn 1995), 229-273.
} 
globalization, the fall of dictatorship, and the 1988 Olympic Games being the underlying temporal key points in these developments. In the case of China, as was mentioned previously, the policies of Deng Xiaoping and Jiang Zemin 江泽民 (most importantly, the so-called ideology of the "Three Represents" 三個代表) are seen as the signifiers of the reinterpretation of Maoism and acceptance of both old indigenous doctrines - such as Confucianism - as well as foreign technology and market economy, with the aim of revitalizing the stagnated and inefficient industry and social productivity..$^{52}$ Regardless of the details of these changes, the Confucian core of interpersonal relations has remained intact, and the domination of men in familial structures and work continues to define East Asian behavioral models. ${ }^{53}$ Another proof of Confucianism's persistence as the dominant system of social interaction is the acceptance of communal values associated with Confucianism in Taiwan, which was proved by Fetzer's and Soper's comparative research, ${ }^{54}$ though the authors also frequently note within their work that there is an increasingly large number of Taiwan's citizens who associate Confucian ideology with policies of the ruling Kuomintang party; the results can be very well applied in mainland China and South Korea as well. The presence of patriarchy, perceived as the key element of familism and communitarian attitude, results in a much higher focus on producing a male heir and rearing him to become a "respectable" member of society than ever practiced in European or American societies. Therefore, it can be seen that the aforementioned cosmopolitanism - being, by definition, focused on relationships with foreign states and cultures - did not replace Confucian values as the main basis for official administration and interpersonal communication. As Daniel A. Bell notes, the younger generations of Chinese Communist Party officials, including the former president $\mathrm{Hu}$ Jintao 胡锦涛, are keen on treating Confucian values (most importantly the filial piety, behaviour towards family members and the widely-perceived higher-in-ranks) as the measuring tool of their morality and public conduct, as well as of the general socio-economic changes within the country. ${ }^{55}$ The authority of Confucius himself is, however, being treated with caution, as evidenced by the case of the statue of the Sage, which was firstly placed on the highly sensitive (in political terms)

\footnotetext{
52 Ruiping Fan, Reconstructionist Confucianism Rethinking Morality After the West (New York: Springer, 2010), 240-241.

${ }^{53}$ Uhn Cho, "Gender inequality and patriarchal order recontextualized," in Hee-Yeon Cho, Lawrence Surrendra and Hyo-Je Cho eds., Contemporary South Korean Society A critical perspective (London and New York: Routledge, 2013), 18-27.

${ }^{54}$ Joel S. Fetzer and Christopher J. Soper, "The Effect of Confucian Values on Support for Democracy and Human Rights in Taiwan," in Taiwan Journal of Democracy, 3:1 (July 2007), 143154 .

${ }^{55}$ Daniel A. Bell, China's New Confucianism Politics and Everyday Life in a Changing Society (Princeton and Oxford: Princeton University Press, 2008), 23-26.

(c) 2014 Tomasz Sleziak http://www.kritike.org/journal/issue 15/sleziak december2014.pdf ISSN 1908-7330

(cc) $\mathrm{BY}-\mathrm{NC}$
} 
Tiananmen Square in Beijing, and then subsequently removed. ${ }^{56}$ Furthermore, the Confucius Institutes have come under international criticism in the recent years, being branded as instruments of China's 'soft power' and political agenda worldwide. ${ }^{57}$ South Korean government has also been supporting Confucian heritage of the country. Designation of Confucian shrines as protected cultural property and recommendation of such culturally significant Confucian heritage as Seowon academies for the UNESCO World Heritage List ${ }^{58}$ are sign of this attitude, though just like their Chinese counterparts, the South Korean politicians are reluctant to let Confucianism gain more public foothold. In the 1995 research report by Helgesen and Thomsen, ${ }^{59}$ a relatively high number of respondents associated Confucianism with such values as authoritarianism and alienation; these results, coupled with other findings outlined by Helgesen and Thomsen, collectively prove both the highly fluid perception of Confucian values in Korea and the survival of the doctrine as an independent, distinguishable system of beliefs.

Despite the seemingly positive premise of the application of Confucianism in the apparatus of the leading party of China (and, by extension, elsewhere in East Asia), the potentially dangerous side to this process is emphasized by Gilbert Rozman. ${ }^{60}$ He points out the morally dubious aspect of assessing a person's worth in Confucianism, which, in his eyes, is largely based on the factor of birth and the widely-perceived social placement. Furthermore, while by the principles expounded by Mencius, the society has a full right of rising against corrupt politicians and administrators, ${ }^{61}$ the authority of the supreme leader (such as the President, Secretary General of the Party, etc.) is frequently seen by the masses and experts alike as unchallengeable. ${ }^{62}$ Rozman's focus on the assessment of a person's hierarchical position and functional capabilities as dependent on

56 Samuel Wade, “Tiananmen Confucius Statue Relocated," in China Digital Times, 21 April 2011, <http://chinadigitaltimes.net/2011/04/tiananmen-confucius-statue-relocated>.

57 D.D. Guttenplan, "Critics Worry About Influence of Chinese Institutes on U.S. Campuses," in New York Times, 4 March 2012, <http://www.nytimes.com/2012/03/05/us/criticsworry-about-influence-of-chinese-institutes-on-us-campuses.html?pagewanted=all\&_r=0>.

${ }^{58}$ Ah-young Chung, "CHA to propose 'seowon' for UNESCO heritage," in Korea Times, 10 December 2013, <https://www.koreatimes.co.kr/www/news/culture/2013/12/386_ 147716.html>.

${ }^{59}$ Geir Helgesen and Soren Risbjerg Thomsen, Measuring Political Attitudes in East Asia The Case of South Korean Democratization (Nordic Institute of Asian Studies, 1995), 34.

${ }^{60}$ Gilbert Rozman, "Can Confucianism Survive in an Age of Universalism and Globalization?," in Pacific Affairs, 75:1 (Spring 2002), 11-37.

${ }^{61}$ A.T. Nuyen "'The 'Mandate of Heaven': Mencius and the Divine Command Theory of Political Legitimacy," in Philosophy East and West, 63:2 (April 2013), 113-126.

${ }^{62}$ Ho-Fung Hung, "Confucianism and Political Dissent in China," in East Asia Forum, 26 July 2011, <http://www.eastasiaforum.org/2011/07/26/confucianism-and-political-dissent-inchina>.

(C) 2014 Tomasz Sleziak http://www.kritike.org/journal/issue 15/sleziak december2014.pdf ISSN 1908-7330 
interpersonal connections-typically in the form of affective networksmostly refers to the structures of the Chinese Communist Party, and he somewhat diminishes the educational aspect of social advancement. In fact, the society at large in mainland China, Taiwan and South Korea treats proper schooling, grades, and examinations as the most basic ways of access to the higher echelons of a state's socio-economic environment.63 Rozman's point, on the other hand, is validated by June Ock Yum who points out the importance of the intermediaries in East Asian professional settings, as opposed to the more personal and direct methods of contact typical to American businesses. ${ }^{64}$ Regardless, certain discrepancies concerning application of Confucian values between East Asian ruling spheres and the societies of the region may be explained by Confucius' own opinion on the rectification of names and divisions of functions. In this regard, Antonio Cua notices the particular opinion of the Sage, according to which the rulers and their advisors, while emulating the functionality of familial structures, should be kept separate from the matters of the rest of the populace, being in tune with their traditional (i.e., at least in part hereditary) prerogatives, official roles, distinct modes of communication and interpersonal relations, despite his stressing knowledge and practical skills as future basis for advancement of all members of society. ${ }^{65}$ Within this ancient tradition, one may surprisingly find not only the roots of divisions in modern East Asia and mechanisms behind affective networks, but also the basis for the contemporary form of oriental authority 'cults.' These 'cults' extend to the spheres of economic activity, perceived-especially the South Korean Chaebol system and Taiwanese traditional family companies - as serving an important role in the financial sustenance of the people and contributing to national pride. ${ }^{66}$ Ties between politicians and the leading conglomerate clans are therefore acceptable in such a setting, despite the frequent corruption, nepotism-based scandals and recruitment of employees based on familial connection and aforementioned affective networks, which, as proven by latest media investigations, pose a significant danger to the fairness of South

\footnotetext{
63 John Sudworth, “China's Students Take on Tough Gaokao University Entrance Exam," in bbc.co.uk, 8 June 2012, < http://www.bbc.co.uk/news/world-asia-china-18349873>.

${ }^{64}$ June Ock Yum, "The impact of Confucianism on Interpersonal relationships and communication patterns in East Asia," in Communication Monographs, 55:4 (1988), 374-388.

${ }^{65}$ Antonio S. Cua, "Reflections on the Structure of Confucian Ethics," in Philosophy East And West, 21:2 (April 1971), 125-140.

${ }^{66}$ Gary G. Hamilton and Nicole Woolsey Biggart, "Market, Culture and Authority: A Comparative Analysis of Management and Organization in the Far East," in American Journal of Sociology, 94, Supplement: Organizations and Institutions: Sociological and Economic Approaches to the Analysis of Social Structure (1988), 52-9.

(C) 2014 Tomasz Sleziak http://www.kritike.org/journal/issue 15/sleziak december2014.pdf ISSN 1908-7330

(cc) BY-NC
} 
Korean, ${ }^{67}$ mainland Chinese, ${ }^{68}$ and Taiwanese ${ }^{69}$ job markets. The frequently asked question of the compatibility of the western democratic models with Confucian social though is thus well-placed. Sor-Hoon Tan understands the frequent "interventionism" of East Asian governments and their ties with kinship structures and economic entities as not only embodying Confucian theory of a "benevolent ruler," but also resembling Dewey's modern view of the necessary degree of influence of the politicians extended over the sphere of economy, aimed at alleviating hardships of society, even at the cost of an individual's personal freedom. ${ }^{70}$

Popular outlooks towards politicians in East Asia, besides being grounded on administrative and age-based hierarchies, are also shaped by regional factors; it is especially in the nominally democratic states such as South Korea, where, in the process of voting, one can freely express his or her allegiance to a politician from his or her geographical area. Wang-Bae Kim sees regional sentiment as an alternative to globalism, and one of the main ideological forces in modern South Korea, especially since the society of that country, in academic and sociological terms, is under the influence of an underlying indigenous-Confucian cultural heritage. ${ }^{71}$ However, Confucian culture finds sustainment not only within private kinship structures, affective networks, or as an aspect of regionalism. In the recent years, Taiwan, mainland China, and South Korea have been producing various televised series and movies concerning the national traditions and history; Confucian communication and moral tenets are often emphasized within such media, ${ }^{72}$ which in turn is an easily accessible and direct method of contact with the ancient doctrine, especially to younger generations, who in their intellectual pursuits usually focus on subjects and skills required for their career, most importantly natural sciences. Moreover, it can be said that while comprehension of the canon of Confucian classics is no longer mandatory in East Asian academic curricula, Chinese and Korean students are constantly exposed to a model of education and examination deeply reminiscent of the

${ }^{67}$ Chosun Ilbo, "Nepotism Still Rife in Korean Employment," in english.chosun.com, 22 November 2011, <http://english.chosun.com/site/data/html_dir/2011/11/22/2011112200372. html>.

${ }^{68}$ Jamil Anderlini, "Bo's Downfall Sheds Light on Nepotism," in Financial Times, 18 April 2013, <http://www.ft.com/cms/s/0/6be8993e-8962-11e1-bed0-00144feab49a.html>.

${ }^{69}$ Yan-Chih Mo, "Councilors Accuse Taipei of Nepotism," in Taipei Times, 18 May 2012, <http://www.taipeitimes.com/News/taiwan/archives/2012/05/18/2003533132>.

70 Sor-Hoon Tan, Confucian Democracy A Deweyan Reconstruction (Albany: State University of New York Press, 2004), 173-175.

${ }^{71}$ Wang Bae Kim, "Regionalism its origins and substance with competition and exclusion," in Hee-Yeon Cho, Lawrence Surrendra and Hyo-Je Cho eds., Contemporary South Korea a Critical Perspective (London and New York: Routledge, 2013), 28-40.

${ }^{72}$ Ying Zhu, "The Confucian Tradition and Chinese Television Today," in The New York Times, 15 May 2013, <http://www.nytimes.com/ref/college/coll-china-media-003.html>. 


\section{CONFUCIAN VALUES}

one advised by Cheng-Zhu school in pre-modern times, with memorization, blind respect for teachers and cooperation with peers, rather than freethinking and individualistic behaviour, being rewarded in the course of one's career. ${ }^{73}$ Various academic projects conducted in recent years further confirm and explain this particular mentality, as well as the general, if partially unconscious, trend of acceptance the younger generations exhibit towards traditional Confucian values. However, the opinions concerning specific aspects of these values tend to vary depending on a country's unique sociohistorical circumstances. ${ }^{74}$ Interpersonal relations modeled on Confucian principles are also present within various forms of entertainment favored by young East Asians, such as internet games, though the pop-culture and modern jargon may make it difficult for a scholar to clearly identify the patterns of traditionalism within such products, especially considering the promotional character at least some of them possess, for instance, as part of the global Korean Wave phenomenon. ${ }^{75}$ Persistence of Confucian values in new media additionally reinforces the traditional morality of Chinese and Koreans in daily life, and despite the aforementioned linguistic changes, the "high speech," "low speech," honorific particles, and various levels of ethnolinguistic hierarchy, along with the deep sense of placement within specific social group-family, friends, company-still influence East Asian interpersonal communication. Whether or not such social organization and behavioral models can survive the rapid aging of East Asian societies and the rising financial discrepancies ${ }^{76}$ is a question the answer to which can only be pinpointed after further investigation and analyses. Based on developments in East Asia so far, one thing can be ascertained - that the transformative aspect of Neo-Confucianism, often hidden behind conservative nature of the doctrine, has definitely contributed to socio-political changes in the region, and that Confucianism, despite the traditional doctrinal opposition from Christianity, Buddhism, Shinto, Shamanism, and other religions of the world, will continue to be noticeable in daily lives of East Asian nations.

\footnotetext{
${ }^{73}$ Kyung Hee Kim, "Learning From Each Other: Creativity in East Asian and American Education," in Creativity Research Journal, 17:4 (2005), 337-347.

74 Yan Bing Zhang, Mei-Chen Lin, Akihiko Nonaka and Khisu Beom, "Harmony, Hierarchy and Conservatism: A Cross-Cultural Comparison of Confucian Values in China, Korea, Japan, and Taiwan," in Communication Research Reports, $22: 2$ (June 2005), 107-115.

75 Yong Jin Dal, "The New Korean Wave in the Creative Industry Hallyu 2.0," in II Journal, 2:1 (Fall 2012), <http://quod.lib.umich.edu/i/iij/11645653.0002.102/--hallyu-20-the-newkorean-wave-in-the-creative-industry?rgn=main;view=fulltext $>$.

${ }^{76}$ Rafal Chomik and John Piggott, "Ageing Societies: The Race Against Time," in East Asia Forum, 9 April 2013, <http://www.eastasiaforum.org/2013/04/09/ageing-societies-a-raceagainst-time/>.

(c) 2014 Tomasz Sleziak

http://www.kritike.org/journal/issue 15/sleziak december2014.pdf

ISSN 1908-7330

(cc) BY-NC
} 


\section{Key Conclusions}

Main geographic, socio-political, and cultural areas of enquiry were limited to social interactions and hierarchism in People's Republic of China, Democratic People's Republic of Korea, Republic of China, Republic of Korea, and their historical predecessors. Whether a state actively supports dissemination of the traditional doctrine or tries to uproot it in favor of foreign ideologies, the fact is that due to several centuries of NeoConfucianism's dominance as the key source of the region's official policies and cultural settings, the societies of China and Korean Peninsula haveperhaps unconsciously-accommodated Neo-Confucian principles as a basis for their day-to-day lives. While in pre-modern history of the sinophone cultural sphere, the differences between Korean and Chinese applications of "sagely teachings" had their source in varying political circumstances and indigenous forms of social organization, at present it is difficult to find functional points of divergence pertaining to support or limitation of Confucianism in mainland China, Taiwan, and both Koreas. The reason for this could lie in the superiority and longevity of Neo-Confucianism displayed so far over other philosophical and metaphysical teachings present in the region-perhaps due to its highly practical nature. Thus, it can be concluded that regardless of China's or Korea's officially adopted political ideologies, or the publicly expressed, highly varying attitudes towards the ancient doctrine, the dualistic conservative-transformative nature of Neo-Confucian heritage will remain the central denominator of the expressed values of Koreans and Chinese and of the interpersonal communication in their daily lives, embodying the internalized, yet visible and distinguishable core of East Asian sociological, philosophical, and ethical heritage.

Department of the Languages and Cultures of Japan and Korea, School of Oriental and African Studies, United Kingdom

\section{References}

Anderlini, Jamil, "Bo's Downfall Sheds Light on Nepotism," in Financial Times, 18 April 2013, <http://www.ft.com/cms/s/0/6be8993e-896211e1-bed0-00144feab49a.html>.

Angurarohita, Pratoom, "Buddhist Influence on the Neo-Confucian Concept of the Sage," in Sino-Platonic Papers, 10 (June 1989).

Baker, Don, "Practical Ethics and Practical Learning: Tasan's Approach to Moral Cultivation," in Acta Koreana, 13:2 (Dec. 2010).

(C) 2014 Tomasz Sleziak

http://www.kritike.org/journal/issue 15/sleziak december2014.pdf

ISSN 1908-7330

$(\mathrm{cc}) \mathrm{BY}$-NC 


\section{8}

CONFUCIAN VALUES

Bell, Daniel A., China's New Confucianism Politics and Everyday Life in a Changing Society (Princeton and Oxford: Princeton University Press, 2008).

Brown, Lucien, Korean Honorifics and Politeness in Second Language Learning (Amsterdam and Philadelphia: John Benjamins Publishing Company, 2011).

Buswell, Robert E. and Timothy S. Lee eds., Christianity in Korea (University of Hawai'I Press, 2006).

Chan, Wing Tsit, A Source Book in Chinese Philosophy (Princeton, New Jersey: Princeton University Press, 1963).

Cheng, Linsun ed., Berkshire Encyclopedia of China (Great Barrington, Massachusetts: Berkshire Publishing Group, 2009).

Cho, Uhn, "Gender inequality and patriarchal order recontextualized," in Hee-Yeon Cho, Lawrence Surrendra and Hyo-Je Cho eds., Contemporary South Korean Society A critical perspective (London and New York: Routledge, 2013).

Choe, Yong-Ho, "Commoners in Early Yi Dynasty Civil Examinations: An Aspect of Korean Social Structure, 1392 - 1600," in The Journal of Asian Studies, 33:4 (Aug. 1974).

Choi, Joon-Sik, Folk-religion, The Customs in Korea (Seoul: Ewha Womans University Press, 2005).

Chomik, Rafal and John Piggott, "Ageing Societies: The Race Against Time," in East Asia Forum, 9 April 2013, <http://www.eastasiaforum.org/ 2013/04/09/ageing-societies-a-race-against-time/>.

Chung, Ah-young, "CHA to propose 'seowon' for UNESCO heritage," in Korea Times, 10 December 2013, <https://www.koreatimes.co.kr/ www/news/culture/2013/12/386_ 147716.html>.

Cook, Scott, "The Debate over Coercive Rulership and the 'Human Way' in Light of Recently Excavated Warring States Texts," in Harvard Journal of Asiatic Studies, 64:2 (Dec., 2004).

Cua, Antonio S., "Reflections on the Structure of Confucian Ethics," in Philosophy East And West, 21:2 (April 1971).

Dal, Yong Jin, "The New Korean Wave in the Creative Industry Hallyu 2.0," in II Journal, 2:1 (Fall 2012), <http://quod.lib.umich.edu/ i/iij/11645653.0002.102/--hallyu-20-the-new-korean-wave-in-thecreative-industry?rgn=main;view=fulltext $>$.

de Bary, William Theodore, Neo-Confucian Orthodoxy and the Learning of the Mind-And-Heart (New York: Columbia University Press, 1981).

Deuchler, Martina, "Neo-Confucianism in Early Joseon Dynasty: Some Reflections on the Role of Ye," in Korean National Commission for UNESCO, eds., Korean Philosophy: Its Tradition and Modern Transformation (Elizabeth, New Jersey and Seoul: Hollym, 2004).

(c) 2014 Tomasz Sleziak

http://www.kritike.org/journal/issue 15/sleziak december2014.pdf

ISSN 1908-7330

(cc) $\mathrm{B} Y-\mathrm{NC}$ 
Deuchler, Martina, "The Practice of Confucianism: Ritual and Order in Choson Dynasty Korea," in Benjamin A. Elman, John B. Duncan and Herman Ooms eds., Rethinking Confucianism: Past and Present in China, Japan, Korea, and Vietnam (Los Angeles: UCLA Asian Pacific Monograph Series, 2002).

Dirlik, Arif, "Confucius in the Borderlands: Global Capitalism and the Reinvention of Confucianism," in Boundary 2, 22:3 (Autumn 1995).

Duncan, John, "The Korean Adoption of Neo-Confucianism: The Social Context," in Walter H. Slote and George A. de Vos eds., Confucianism and the Family (Albany: State University of New York Press, 1998).

Ebrey, Patricia Buckley, Confucianism and Family Rituals in Imperial China A Social History of Writing About Rites (Princeton, New Jersey: Princeton University Press, 1991).

Elman, Benjamin A. and Alexander Woodside eds., Education and Society in Late Imperial China, 1600 - 1900 (Berkeley: University of California Press, 1994).

Fairbank, John K., Edwin O. Reischauer and Albert M. Craig, East Asia The Modern Transformation (Boston: Houghton Mifflin Company, 1965).

Fan, Ruiping, Reconstructionist Confucianism Rethinking Morality After the West (New York: Springer, 2010).

Fetzer, Joel S. and Christopher J. Soper, "The Effect of Confucian Values on Support for Democracy and Human Rights in Taiwan," in Taiwan Journal of Democracy, 3:1 (July 2007).

French, Paul, North Korea The Paranoid Peninsula A Modern History (London and New York: Zed Books, 2005).

Guttenplan, D.D., "Critics Worry About Influence of Chinese Institutes on U.S. Campuses," in New York Times, 4 March 2012, $<$ http://www.nytimes.com/2012/03/05/us/critics-worry-aboutinfluence-of-chinese-institutes-on-us- campuses.html?pagewanted= all\&_r $=0>$.

Hamilton, Gary G. and Nicole Woolsey Biggart, "Market, Culture and Authority: A Comparative Analysis of Management and Organization in the Far East," in American Journal of Sociology, 94, Supplement: Organizations and Institutions: Sociological and Economic Approaches to the Analysis of Social Structure (1988).

Helgesen, Geir and Soren Risbjerg Thomsen, Measuring Political Attitudes in East Asia The Case of South Korean Democratization (Nordic Institute of Asian Studies, 1995).

Hong, Xiuping, "The Characteristics and Prospect of the Confucian Academy: A Commentary on Jiang Qing's Ideas on the Confucian Academy," in Fan Ruiping ed., The Renaissance of Confucianism in Contemporary China (New York: Springer, 2011).

(C) 2014 Tomasz Sleziak http://www.kritike.org/journal/issue 15/sleziak december2014.pdf ISSN 1908-7330 
Hung, Ho-Fung, "Confucianism and Political Dissent in China," in East Asia Forum, 26 July 2011, <http://www.eastasiaforum.org/2011/07/26/ confucianism-and-political-dissent-in-china>.

Ilbo, Chosun, "Nepotism Still Rife in Korean Employment," in english.chosun.com, 22 November 2011, <http://english.chosun.com/ site/data/html_dir/2011/11/22/2011112200372.html>.

Jenco, Leigh K., “'Rule by Man' or 'Rule by Law' in Early Republican China: Contributions to a Theoretical Debate," in The Journal of Asian Studies, 69:1 (Feb. 2010).

Kim, Kyung Hee, "Learning From Each Other: Creativity in East Asian and American Education," in Creativity Research Journal, 17:4 (2005).

Kim, Uichol and Seung-hwan Lee, "The Confucian Model of Morality, Justice, Selfhood and Society: Implications for Modern Society," in The Universal and Particular Natures of Confucianism, Proceedings of The $8^{\text {th }}$ International Conference on Korean Studies (The Academy of Korean Studies, 1994).

Kim, Wang Bae, "Regionalism its origins and substance with competition and exclusion," in Hee-Yeon Cho, Lawrence Surrendra and Hyo-Je Cho eds., Contemporary South Korea a Critical Perspective (London and New York: Routledge, 2013).

Kim, Yung Sik, The Natural Philosophy of Chu Hsi 1130 - 1200 (American Philosophical Society, 2000).

Lee, Ki-Moon and Robert S. Ramsey, A History of Korean Language (New York: Cambridge University Press, 2011).

Lee, Peter H. and Theodore de Bary eds., Sources of Korean Tradition Vol.I (New York: Columbia University Press, 1997).

Lee, Tien-Rein, "Heaven, Earth and Humans: Color Harmony in Chinese Culture," in Obuda University e-Bulletin, 3:1 (2012), 155-164, 29 December 2014, <http://uni-obuda.hu/e-bulletin/Lee_3.pdf >.

Lewis, Mark Edward, China's Cosmopolitan Empire the Tang Dynasty (Cambridge, Massachusetts and London: The Belknap Press of Harvard University Press, 2009).

Liu, Henry C.K., “Korea Under Park Chung-Hee," in Asia Times, 25 October 2006, <http://www.atimes.com/atimes/Korea/HJ25Dg01.html>.

Liu, Shu-Hsien, Essentials of Contemporary Neo-Confucian Philosophy (Westport, Connecticut, London: Praeger, 2003).

McKnight, Brian E., Law and Order in Sung China (Cambridge, USA: Cambridge University Press, 1992).

Mo, Yan-Chih, "Councilors Accuse Taipei of Nepotism," in Taipei Times, 18 May 2012, <http://www.taipeitimes.com/News/taiwan/archives/ 2012/05/18/2003533132>.

(C) 2014 Tomasz Sleziak

http://www.kritike.org/journal/issue 15/sleziak december2014.pdf

ISSN 1908-7330

(cc) BY-NC 
Nuyen, A.T., “'The 'Mandate of Heaven': Mencius and the Divine Command Theory of Political Legitimacy," in Philosophy East and West, 63:2 (April 2013).

Palais, James B., "Confucianism and The Aristocratic/Bureaucratic Balance in Korea," in Harvard Journal of Asiatic Studies, 44:2 (Dec. 1984).

Peerenboom, Randall, China Modernizes threat to the west or model for the rest? (Oxford and New York: Oxford University Press, 2007).

Peterson, Mark and Philipp Margulies, A Brief History of Korea (New York: Infobase Publishing, 2010).

Reischauer, Edwin O. and John K. Fairbank, East Asia The Great Tradition (Boston: Houghton Mifflin Company, 1960), 186-187.

Richey, Jeffrey, Confucianism Historical Development Modern Age, in Patheos Library, 8 May 2013, <http://www.patheos.com/Library/ Confucianism/Historical Development/Modern-Age.html>.

Ropp, Paul S. ed., Heritage of China Contemporary Perspectives on Chinese Civilization (Berkeley: University of California Press, 1990).

Rozman, Gilbert, "Can Confucianism Survive in an Age of Universalism and Globalization?," in Pacific Affairs, 75:1 (Spring 2002).

Schwartz, Benjamin I., The World of Thought in Ancient China (Cambridge, Massachusetts: Harvard University Press, 1989).

Seth, Michael J., A History of Korea From Antiquity to the Present (Plymouth, UK: Rowman and Littlefield Publishers Inc., 2011).

Shin, Gi-Wook, Ethnic Nationalism in Korea Genealogy Politics and Legacy (Stanford, California: Stanford University Press, 2006).

Sim, Luke J., S.J. and James T. Bretzke, S.J., “The Notion of Sincerity (Ch'eng) in The Confucian Classics," in Journal of Chinese Philosophy, 21 (1994).

Sorensen, Henrik, "The Attitude of the Japanese Colonial Government Towards Religion in Korea (1910-1919)," in Copenhagen Papers in East and Southeast Asian Studies, 8 (1993).

Sudworth, John, "China's Students Take on Tough Gaokao University Entrance Exam," in bbc.co.uk, 8 June 2012, <http://www.bbc.co.uk/ news/world-asia-china-18349873>.

Sullivan, Lawrence R., "Intellectual and Political Controversies Over Authority in China: 1898 - 1922," in Peter D. Hershock and Roger T. Ames eds., Confucian Cultures of Authority (Albany: State University of New York Press, 2006).

Tan, Soo Kee, "Influences of Confucianism on Korean Corporate Culture," in Asian Profile, 36:1 (2008).

Tan, Sor-Hoon, "Can there be a Confucian Civil Society," in Chong KimChong and Tan Sor-Hoon eds., The Moral Circle and The Self (Chicago and La Salle, Illinois: Open Court, 2003).

(C) 2014 Tomasz Sleziak http://www.kritike.org/journal/issue 15/sleziak december2014.pdf ISSN 1908-7330 


\section{2}

CONFUCIAN VALUES

Confucian Democracy A Deweyan Reconstruction (Albany: State University of New York Press, 2004).

Taylor, Romeyn, "Chinese Hierarchy in Comparative Perspective," in The Journal of Asian Studies, 48:3 (Aug. 1989).

Voltaire, "Selections from the Philosophical Dictionary," 1-2, accessed December 29 2014, <http://homepages.gac.edu/ arosenth/160/ Voltaire_Selections.pdf $>$.

Wade, Samuel, "Tiananmen Confucius Statue Relocated," in China Digital Times, 21 April 2011, <http://chinadigitaltimes.net/2011/04/ tiananmen-confucius-statue-relocated $>$.

Yan, Yunxiang, "The Individualization of Chinese Society," in London School of Economics Monographs on Social Anthropology, 77 (2009).

Yao, Xinzhong, An Introduction to Confucianism (New York: Cambridge University Press, 2000).

Yum, June Ock, "The impact of Confucianism on Interpersonal relationships and communication patterns in East Asia," in Communication Monographs, 55:4 (1988).

Zhang, Yan Bing, Mei-Chen Lin, Akihiko Nonaka and Khisu Beom, "Harmony, Hierarchy and Conservatism: A Cross-Cultural Comparison of Confucian Values in China, Korea, Japan, and Taiwan," in Communication Research Reports, 22:2 (June 2005).

Zhu, Ying, "The Confucian Tradition and Chinese Television Today," in The New York Times, 15 May 2013, <http://www.nytimes.com/ref/college/ coll-china-media-003.html>. 